\title{
First Report of Rose rosette virus Associated with Rose Rosette Disease in Rosa hybrida in Minnesota
}

Sara Bratsch, Department of Plant Pathology, University of Minnesota, St. Paul, MN 55108; David Zlesak, Department of Plant and Earth Science, University of Wisconsin-River Falls, River Falls, WI 54022; Dimitre Mollov, USDA-ARS, National Germplasm Resources Laboratory, Beltsville, MD 20705; and Benham Lockhart, Department of Plant Pathology, University of Minnesota, St. Paul, MN 55108

Accepted for publication 10 May 2017.

Garden or landscape roses, Rosa spp. (family Rosaceae), are woody perennials frequently planted in gardens and commercial landscapes for their flowers. Recent breeding efforts have produced cold-hardy, colorful, disease- and heat-tolerant plants that have greatly increased the popularity of roses (Pemberton and Karlik 2013).

A single R. hybrida Above and Beyond ('ZLEEltonStrack') plant was identified in a public garden in Carver Co., MN, in September 2015 with rose rosette disease (RRD) like symptoms. The plant exhibited abnormal, late-season, lateral shoot growth, abundant red pigmentation, excessive thorniness, and witches'-broom (Fig. 1). RRD symptoms are characteristic of Rose rosette virus (RRV) infected plants (Laney et al. 2011).

RRD causing witches'-broom of rose was first noted in 19401941 in Manitoba, California, Nebraska, and Wyoming (Conners 1941). RRD is widespread throughout the South, the Midwest, and east of the Rocky Mountains (Martin 2014), and is the most destructive rose virus in the United States (Dobhal et al. 2016). RRV, the causal agent of RRD, from Arkansas, was sequenced in 2011 and a molecular diagnostic test was created (Laney et al. 2011).

Total RNA was extracted (RNeasy Plant Mini Kit, Qiagen, Frederick, MD) from symptomatic tissue and tested by reversetranscription polymerase chain reaction (RT-PCR) (illustra Readyto-Go beads; GE Healthcare Life Sciences, Marlborough, MA) using RRV detection primers (Laney et al. 2011) designed to amplify a region of RNA1. No amplification products were observed, which is consistent with a report by Dobhal et al. (2016) of difficulty detecting all RRV positive samples using those primers.

New primers were designed (Primer-BLAST) based on conserved RRV sequences from RNA3 and RNA4 (15 sequences for both) available from NCBI and amplify partial coding regions of the putative nucleocapsid and movement proteins (Table 1). They were used in RT-PCR with reaction conditions of $42^{\circ} \mathrm{C}$ for $45 \mathrm{~min}$, and $94^{\circ} \mathrm{C}$ for $5 \mathrm{~min}$; and 30 cycles of $94^{\circ} \mathrm{C}$ for $30 \mathrm{~s}, 58^{\circ} \mathrm{C}$ for $30 \mathrm{~s}$, and $72^{\circ} \mathrm{C}$ for $30 \mathrm{~s}$, followed by an extension of $10 \mathrm{~min}$ at $72^{\circ} \mathrm{C}$. The reactions yielded 411-nt and 475-nt products for the RNA3 and RNA4 targets, respectively (Fig. 2).

The amplicons were purified, ligated, and cloned (pGEM-T Easy Vector System; Promega, Madison, WI). Four clones were sequenced in both directions for both amplicons (MCLAB; South San Francisco, CA). The consensus sequences (Sequencher 5.1; Gene Codes Corp., Ann Arbor, MI) were deposited in GenBank (Accession Nos. KU195474 and KU195475). The RNA3 product had $100 \%$ query coverage and $99 \%$ nucleotide identity $(\mathrm{E}$ value $=0.0)$

Corresponding author: Sara Bratsch; E-mail: brats011@umn.edu

(C) 2017 The American Phytopathological Society to deposited RRV RNA3 sequences (KT835651.1, HQ891903.1, and 15 more). The RNA4 product had $100 \%$ query coverage and $99 \%$ nucleotide identity $(\mathrm{E}$ value $=0.0)$ to RRV RNA4 sequences (HQ89189.1, HQ871945.1, and 12 more), thus confirming the symptomatic rose is infected with RRV.

It is likely the rose, which was planted in spring 2015, was infected naturally. This cultivar was bred in Minnesota and the commercial supply chain had not yet left Minnesota. It was clonally propagated by cuttings (own-root) and not grafting onto rootstock. Additional Above and Beyond plants, from the commercial nursery licensed to produce these roses, were screened for symptoms but none were observed. Five random rose samples were tested as above and yielded negative reactions. The public garden from which the symptomatic plant originated was surveyed for roses with RRD symptoms. None were observed in the fall of 2015 or the summer of 2016.

RRV has been found in the bordering states of Wisconsin and Iowa and in the Canadian province Manitoba. The native Woods rose ( $R$. woodsii) and invasive $R$. multiflora are found throughout Minnesota and neighboring states, and are thought to be a reservoir of RRV and the eriophyid mite vector (Phyllocoptes fructiphilus) (Martin 2014; Amrine 1996). Phyllocoptes fructiphilus is easily disseminated by wind and has been found throughout the United States (Amrine 1996).

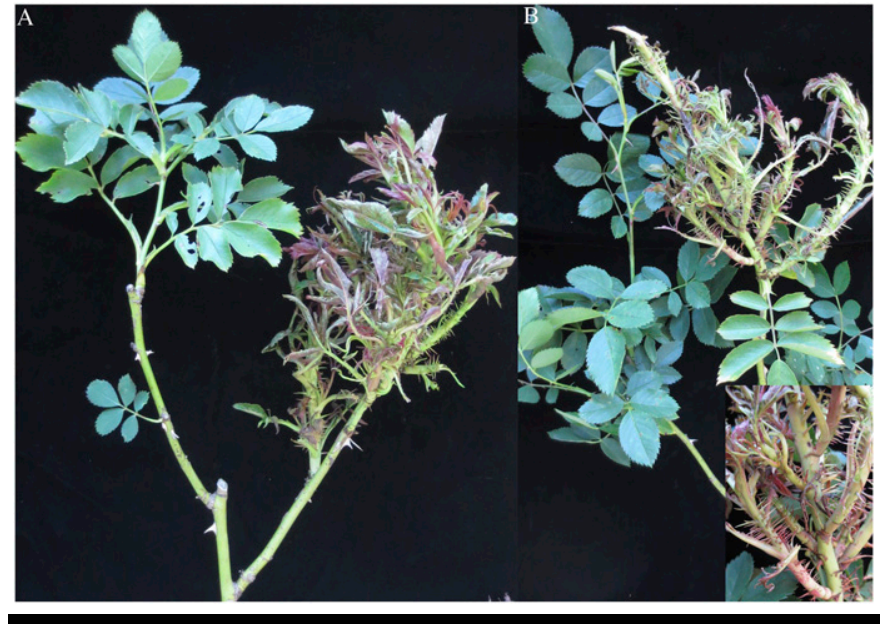

FIGURE 1

Rosa hybrida Above and Beyond ('ZLEEltonStrack') exhibiting symptoms of abnormal late season lateral shoot growth, abundant red pigmentation, excessive thorniness (inset, B), and witches'-broom. 


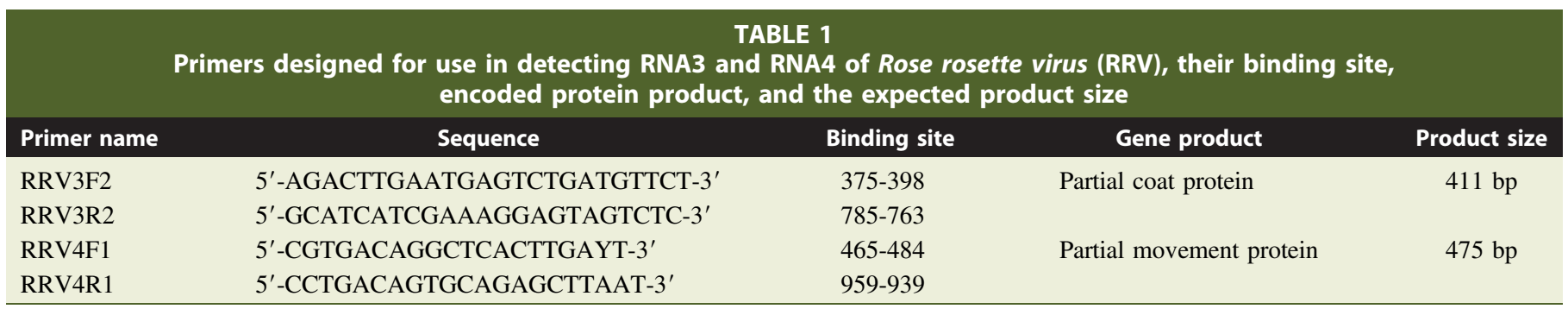

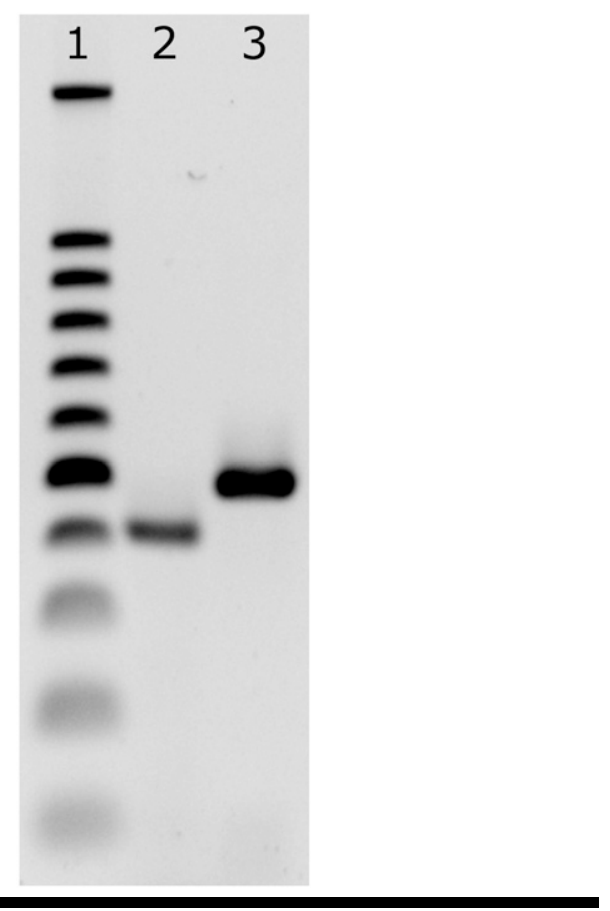

\section{FIGURE 2}

Reverse transcription polymerase chain reaction result: Lane 1, 100 base pair ladder; Lane 2 and 3, amplicons from symptomatic Rosa hybrida Above and Beyond ('ZLEEltonStrack') using primers RRV3F2+R2 (411-bp product) and RRV4F1+R1 (475-bp product), respectively.
The wide distribution of introduced or native roses in Minnesota, the presence of both RRV and its vector $P$. fructiphilus in adjacent areas, and our inability to trace the infection back to infected source plants all supports the conclusion this rose was infected naturally. To our knowledge, this is the first report of RRV infecting rose in Minnesota.

\section{Literature Cited}

Amrine, J. W. 1996. Phyllocoptes fructiphilus and biological control of multiflora rose. Pages 741-749 in: World Crop Pests, Vol. 6, Eriophyoid Mites: Their Biology, Natural Enemies and Control. E. E. Lindquist, M. W. Sabelis, and J. Bruin, eds. Elsevier Science B.V., Amsterdam, The Netherlands.

Conners, I. L. 1941. Annu. Rep. Can. Plant Rep. Surv. 20th. 1940:98.

Dobhal, S., Olson, J. D., Arif, M., Suarez, J. A. G., and Ochoa-Corona, F. M. 2016. A simplified strategy for sensitive detection of Rose rosette virus compatible with three RT-PCR chemistries. J. Virol. Methods 232:47-56.

Laney, A. G., Keller, K. E., Martin, R. R., and Tzanetakis, I. E. 2011. A discovery 70 years in the making: Characterization of the Rose rosette virus. J. Gen. Virol. 92:1727-1732.

Martin, C. W. 2014. Rose rosette disease and the impacts on propagation. Acta Hortic. 1055:319-321.

Pemberton, H. B., and Karlik, J. F. 2013. A recent history of changing trends in USA garden rose plant sales, types, and production methods. Acta Hortic. 1064:223-234. 